\title{
THE STUDY ON THE SEPARATION OF OWNERSHIP AND CONTROL OF MALAYSIAN COMPANIES
}

\author{
Kamaliah Salleh ${ }^{1}$ \\ Faculty of Law and International Relations, \\ (UniSZA), Malaysia \\ (Email: kamaliahsalleh@unisza.edu.my) \\ Noor 'Ashikin Hamid' \\ Faculty of Law and International Relations, \\ (UniSZA), Malaysia \\ (Email: shikin@unisza.edu.my) \\ Noraida Harun ${ }^{3}$ \\ Faculty of Law and International Relations, \\ (UniSZA), Malaysia \\ (Email: noraida@unisza.edu.my) \\ Asiah Bidin ${ }^{4}$ \\ Faculty of Law and International Relations, \\ (UniSZA), Malaysia \\ (Email: asiah@unisza.edu.my) \\ Zuhairah Ariff Abd Ghadas 5 \\ Faculty of Law and International Relations, \\ (UniSZA), Malaysia \\ (Email: zuhairahariff@unisza.edu.my)
}

Accepted date: $22-02-2019$

Published date: 10-07-2019

To cite this document: Salleh, K., Hamid, N. A., Harun, N., Bidin, A., \& Abd Ghadas, Z. A. (2019). The Study on The Separation of Ownership and Control of Malaysian Companies. International Journal of Law, Government and Communication, 4(15), 36-44.

DOI: $10.35631 / \mathrm{ijlgc} .415005$

\begin{abstract}
The members own the company by virtue of their shareholding and the directors manage and exercise control over the company's affairs through the company's board meeting. Despite of segregation of powers and roles between the members and directors, there has been inclination on the part of the members to participate to greater extent in the company's affairs. This paper aims to establish the legal position as between the directors and members that reflect separation of control and ownership in the company under the common law and the Malaysian law. The method used in this study is content analysis of the reported Malaysian and international law cases as well as the statutory provisions in order to examine the legal position established under the common law, the previous Companies Act 1965 and the newly introduced Companies Act 2016. The study reveals that the separation between the two has long been recognised and upheld by the common law as well as the Malaysian Acts. The introduction of the section 195 of the Companies Act 2016 however allows members to raise their voice in relation to matters which are within the powers of directors, hence the separation becomes slightly vague. In the absence of the latest judicial decisions to test the application of
\end{abstract}


section 195, further review on its application may be required in order to determine methods to measure if a members' recommendation is truly made in the best interests of the company.

Keywords: Company, Division Of Powers, Members, Directors

\section{Introduction}

Members and directors have two completely different roles in a company. The members own the company by owning its shares and the directors manage it. This can be seen for the common law principles which reserves the power to control and decide in the company's management to its board of directors, while members can exercise certain rights and interests based on the terms of their shares and the constitution through the general meetings. Basically, directors of a company are usually elected by the members at the annual general meeting. The main task of the directors is to govern the company on behalf of the members. In electing a new board of directors, the members are, in effect, giving control of the company to this new board up to certain tenure. That is the reason why shareholders are said to have great influence on the management of a company (Zeitlin, 1974).

Nevertheless, the separation of ownership and control between members and directors can sometime cause confusion in company management. This is because there are also questions or subjects which can be decided by the directors, but only with the members' prior consent, or there are also situations where members attempt to raise questions or wish to interfere in the decisions passed by the board of directors. Therefore, this paper aims to establish whether the separation of control and ownership between the directors and members are clearly established under the common law and the Malaysian law. The method used in this study is content analysis of the reported Malaysian and international law cases as well as the statutory provisions. The analysis on the legal position of the separation of ownership and control will be made in respect of three positions, namely the common law, the previous Companies Act 1965 and the newly introduced Companies Act 2016.

\section{Literature Review}

It has been argued that the separation of ownership and control model ensures high quality directors, as the directors are basically appointed by members based on merit to run and manage the companies, and they are separated from the membership of the company (McConvill,J., 2004). This support the purpose for company laws around the globe to commonly adopt this model and only allows members to take step in company's affairs in only one of three circumstances, namely: alteration of the company's constitution; decisions relating to major investment directions which have consequences on the management decisions (for example, the decision whether to merge the company with another company towards business expansion); and decisions on matters where the directors are in conflict (Davies, 2000). Nevertheless, the separation between ownership (shareholders) and control (directors) and its relevance for company value and decisions makes it necessary to draw up management control mechanisms (Lopez, 2018). In this respect, Mohd Sulaiman (2008) has earlier highlighted that there are four important principles about the management structure of companies, namely:

i. Both the board of directors and members are organs of a company.

ii. Each organ of the company has power to make particular decisions and is sovereign with respect to those decisions.

iii. The respective powers of each organ of the company are subject to the company's articles or constitution. 
iv. That power is a power to act as the company (and therefore binding the company) or to delegate the power.

By looking at the above clear principles of management structure of companies and the development of the corporate governance, it can be said that the reality of the separation between ownership and control in respect of positions of shareholders and directors is said to have has found its legitimacy (Segrestin, 2018).

Despite the claim of its legitimacy, it has also long been recognised that the separation of ownership from control caused a core problem in the agency relationship between the directors and the shareholder (Berle \& Means, 1932). It cannot be ignored that sometimes, conflicts of interest do occurs between the members and the directors, especially when the directors decide to enter into dealings on behalf of the company which are not in accordance with the shareholders' preference (Ramly, 2010). Gillan \& Starks (2000) state that the conflict of interest between the directors (who exercise control) and shareholders (being the owners), led to a new evolution in stock market function in order to control the conflict. For example, there is an inherent monitoring function in the stock market to monitor the managers or directors to found their decisions in the company without ignoring the interests of the shareholders. Rampling (2012) states that major shareholders in a company are considered to be a category of persons who have been motivated to actively participate in the company's strategic direction. This is one form of inclination on the part of the shareholders to interfere in the control of the company. Therefore, Khan (2011) presented her view that the ownership and control problems can only be resolved by properly drawing a clear line between the shareholder and the directors. That is the reason for various codes of corporate governance are developed and reviewed around the world in order to mitigate and manage the conflicts between the two.

\section{The Derivation of the Separation of Ownership and Control Model}

\section{The Common Law Position}

The development of a separate board of directors to manage or govern or oversee a company has occurred incrementally and indefinitely over legal history. In its early stage until the end of the $19^{\text {th }}$ century, the position was that the board of directors basically acted as an agent of the company and this position is subject to the control of the members in general meeting who was considered to be the supreme organ of a company (Isle of Wight Rly Co v Tahourdin (1884) LR 25 Ch D 320).

Nevertheless, the above position went through a momentous transformation when the English Court of Appeal in 1906 through its the decision in the case of Automatic Self-Cleansing Filter Syndicate Co Ltd v Cuninghame [1906] 2 Ch 34 had made it clear that the division of powers between the board of directors and their members in general meaning rested on the construction of the company's constitution or of its articles of association. Under this construction, where the board exercised its management decisions based on the powers vested on them in the articles, the general meeting could not impede with their lawful exercise. The articles of the company operates as a contract by which the members had agreed that "the directors and the directors alone shall manage" (Per Cozens-Hardy LJ at 44). This case decision basically reflects the principle that members and directors are respectively sovereign with regard to their decision making powers.

The new approach did not secure immediate approval, but it was endorsed by the House of Lords in Quin \& Axtens $v$ Salmon [1909] AC 442 and has since received general acceptance. 
Under English law, successive versions of Table A have reinforced the norm that, unless the directors are acting contrary to the law or the provisions of the Articles, the powers of conducting the management and affairs of the company are vested in them. The modern doctrine was expressed in John Shaw \& Sons (Salford) Ltd $v$ Shaw [1935] 2 KB 113 by Greer $\mathrm{LJ}$ as follows:

"A company is an entity distinct alike from its shareholders and its directors. Some of its powers may, according to its articles, be exercised by directors, certain other powers may be reserved for the shareholders in general meeting. If powers of management are vested in the directors, they and they alone can exercise these powers. The only way in which the general body of shareholders can control the exercise of powers by the articles in the directors is by altering the articles, or, if opportunity arises under the articles, by refusing to re-elect the directors of whose actions they disapprove. They cannot themselves usurp the powers which by the articles are vested in the directors any more than the directors can usurp the powers vested by the articles in the general."

In Howard Smith Ltd v Ampol Petroleum Ltd [1974] AC 821, both Smith and Ampol held shares in Millers. The case arose out of a dispute between the two companies in relation to the takeover of Millers. The combined shareholding in Millers of Ampol and Bulkships (a company with which Ampol was associated) was 55\%. Ampol made a takeover bid to the board of Millers, but it was rejected by the directors of Millers for being too low. Later, a higher takeover bid was followed by Smith. In response to this, Ampol and Bulkships issued a joint statement that they had decided to "act jointly in relation to the future operation" of Millers and reject any proposal to sell the company's shares to Smith. The board of directors of Millers then came up with issue of shares to Smith. Consequently, Smith became the majority shareholder in Millers. In the Supreme Court, Street J found that (as in Teck Corporation V Millar) the directors had not been motivated by any improper desire to retain control. However, it was held that their manner of exercising powers to issue shares in favour of Smith was for an improper purpose, and was regarded to be unlawful. The Privy Council further hold that the directors' exercise of their powers to determine the sale price of the company's shares could not be regarded as a proper purpose.

In the course of deliberation, the Privy Council in the above case nevertheless highlighted that directors, within their management powers, may take a decision, and such decision may not necessarily be in accordance with the wishes of members, and in such situation, members cannot interfere with the directors' powers.

\section{The Position in Malaysia under the Companies Act 1965}

The basis on which decision making is divided depends on the law and the company's articles of association ("AOA"). The effect of the legal rules governing division of powers: a decision properly made by the appropriate body (ie members or directors as the case may be) is a decision of the company. Hence, the collective decision of the board or the collective resolution at a general meeting are treated as a matter of law as decisions of the company. They are acting as what is referred to as organs of the company.

The directors are vested with powers to decide on management issues. In general, directors have power in respect of decisions relating to management of company. Under Table A, the scope of the directors' power of management is set out in Article 73. The effect of Article 73 is that the board of directors has power to decide all matters other than those expressly reserved to the members. A company may also choose to adopt provision in AOA that confers more limited powers on the directors than that conferred by Article 73. For example, the AOA may 
require the consent of members before the company's proceed to involve in transactions for more than certain value. However, company law recognises certain extensions of the general meeting's decision making powers in exceptional circumstances, relating to the decision to instigate litigation, the question of ratification of breach of directors' duties and also in situation where the board of directors are unable to act.

As for members, the Companies Act 1965 reserves certain decision power to the members in general meeting to adopt, modify or repeal the memorandum and/or articles of associations, to veto certain reductions of capital as well as to remove directors from office, veto certain related parties transactions and remove /appoint auditor (public companies). In addition, the AOA may further confer voting rights on members.

As for the member's residual power, the law recognizes their powers in the following circumstances, namely:

- Where the board of directors is unable to act (Mohd Sulaiman, 2008)

- $\quad$ To commence and prosecute legal proceedings, where the alleged wrongdoers control the company (Mohd Sulaiman, 2008); and

- To ratify directors' acts (in the case of 'honest' breach of duties) (Mohd Sulaiman, 2008).

Members cannot override its board's decision. As duly discussed in the case of Automatic SelfCleansing Filter Syndicate Co Ltd v Cuninghame [1906] 2 Ch 34, where the court found in favour of the directors on the issue whether decision to sell the company's assets and undertaking was regarded as a management decision. Based on the AOA, it was within the power of the board of directors to decide. Therefore, the members could not use the resolution to replace the decisions duly made by the board of directors within its powers.

One local case has recently been decided which uphold the separation of ownership and control model in this country.

In Tengku Dato' Ibrahim Petra bin Tengku Indra Petra v Petra Perdana Bhd [2018] 2 MLJ 177 , one of the main issues was the division of powers between the shareholders in a general meeting and the board of directors. The question posed to the Federal Court was whether the powers of management conferred on the board of directors by the Companies Act 1965 and the articles of association of the company could be overridden by way of an ordinary resolution passed by a simple majority of members at a general meeting.

The Federal Court answered the question in the negative, holding that shareholders may only override the powers of the directors by altering the articles to take away the powers of the directors, or, by refusing to re-elect the directors of whose actions they disapprove. Statutory force to this legal position can be found in section 131B of the Companies Act 1965 which provides that "the business and affairs of a company must be managed by, or under the direction of, the board of directors", subject to "any modification, exception or limitation contained in the Act or in the memorandum or articles of association of the company."

Furthermore, the articles of association of the company had expressly set out that the business affairs of the Company shall be managed by the directors with the exception, inter alia, that the directors' exercise of powers were subject to "these regulations" and the Companies Act 1965. The Federal Court (in upholding the High Court Decision) held that the reference to "regulations" means regulations as envisaged under the Companies Act 1965 and not resolutions passed by members at a general meeting, and as such, the directors were not bound 
to comply with the members' resolution. Further, the directors were not deprived of their power to deal with the company's shares in accordance with the Companies Act 1965 and the articles of association.

Based on the above decision, if members dissatisfy with a decision made by the board of directors on the management issue or in any matters within the board's powers, members may take steps to remove the said directors from his office and replace with new one. To do this, members need to do requisition for general meeting in order to consider such resolution pursuant to sections 144 and 145 of the Companies Act 1965. In addition, Lee Shih (2018) also mentioned that the above decision, although was decided in light of the Companies Act 1965, relatively provides guidance that enlightens the division of powers between the directors and members in a company.

\section{The Position in Malaysia under Companies Act 2016}

The common law principle which reserves the power to control and manage company's affairs to its board of directors can still be found in the Companies Act 2016. This is by virtue of section 211 which expressly provides that the business and affairs of a company are vested with the board of directors. At the same, the Companies Act 2016 continues to recognise certain rights and interests can be exercised by the members of the company through general meeting.

The Companies Act 2016 however incorporate a new section 195 which gives the rights to members to question, discuss, comments and make recommendations at general meetings (Chan, 2017). Section 195 allows members to participate in the management of the company by extending their recommendation to the board of directors. Such recommendation can be made through members' general meeting. This provision stipulates on the members' rights for management review. Subsection (1) provides that the chairperson of a meeting of members of a company shall allow a reasonable opportunity for members at the meeting to question, discuss, comment or make recommendation on the management of the company. Subsection (2) states that a meeting of members may pass a resolution under that section which makes recommendations to the Board on matters affecting the management of the company. Subsection (3) further states that any recommendation made under subsection (2) shall not be binding on the Board, unless the recommendation is in the best interest of the company, provided that: (a) the rights to make recommendations is provided for in the constitution, or (b) passed as a special resolution.

The above provision basically introduces two different natures of recommendations which can be extended by members to the board of directors pertaining to management matters of the company. The first one is non-binding recommendation, and the other is binding recommendation on the board of directors subject to fulfilment of the either two conditions stated in the subsection (3). Compared to the Companies Act 1965, there is no similar provision in respect of members' rights for management review. Previously, management and decisionmaking are vested in the Board and as regulated under the articles of association (s131B and Article 73 of Table A).

The new inclusion of section 195 which operates as platform for members to voice their views and to express their concerns to the directors, and where the directors can take into account these views and recommendations made to them is considered to be one of the main key changes under the Companies Act 2016 (Lee, 2017). 
However, such inclusion has invited different opinions by the legal experts in Malaysia. Chan (2017) highlighted that, by allowing members to interfere in the management of the company, the separation of powers between members and their directors becomes blur, and further, it is not clear as who should determine whether the recommendation made by the members is in the best interest of the company.

Mohd Sulaiman (2018) also deliberated the conflict between section 195 which has effect to a member's right to requisition a meeting and the traditional view which prevents members from calling a meeting of members in order to pass a resolution on matters which is within the directors' powers. This traditional view was established in the case of NRMA Ltd v Parker (1986) 6 NMSWLR 517. In this case, a members meeting was held to demand the board of directors to hold the directors election using certain method. The company's constitution stipulated that the manner for the election to be conducted is vested with the directors. So, it was held by the court the members could not propose a resolution as the matter exclusively fell within the powers of the directors.

With regard to the question as to who should determine whether members' recommendation is in the best interest of the company or not, there has been no recent court decision to deliberate on this question. Nevertheless, if we refer to the case of In Re Smith And Fawcett Ltd [1942] Ch 304, Lord Greene MR has decided that the primary duties of a director imposed by the general law is that he should act in what he considers to be the best interests of the company, and not for any collateral purpose. In this respect, the directors are in position to exercise their discretionary powers bona fide in what they consider to be in the interests of the company, and not what the court consider to be in the interests of the company. Based on this decision, it is clear that the court incline to leave the question on what is in the best interest of the company in the hands of the board of directors. Therefore, in light of section 195 where members attempt to raise the recommendation on the basis that it is in the best interest of the company, it could be difficult for the recommendation to be binding on the board of directors, if the board have different view with the members.

Further, if we carefully read subsection 195(3)(a) \& (b), a recommendation shall be binding if it is in the best interest of the company and such rights is provided for in the constitution OR it is passed as a special resolution. Based on the above reading, it can established that members can make a recommendation even if such right is not provided by the company's constitution. Further, the recommendation can be made binding on the board provided that it is passed in the best interest of the company and that it is a special resolution. To sum up, section 195 provides avenue for members to voice their recommendation irrespective whether the company's constitution provides for such rights or not to their members.

\section{Conclusion}

Members in general meetings traditionally do not control the powers of management which fall within the powers of directors. This has been established by virtue of the common law cases and the statutory provisions of the Companies Act 1965 together with cases. The members can never interfere in the company management except that they can only alter the relevant articles of association in respect of removal of the directors from his office and replacing him with a new one which is more amenable to members. This can only be done through members' general meeting. The new Companies Act 2016 also recognised the separation of members' ownership and directors' control of the company. The introduction of section 195 of the Companies Act 2016 somehow rather disturbs the clear separation of ownership and control of companies by opening a door for members to convey their 
recommendation pertaining to management matters of the company to their board of directors, and further, such recommendation also binds the board the directors provided it fulfils the requirements as stipulated in said section 195. In the absence of the latest judicial decision to test the application of section 195, further review on its application may be required in order to determine methods to measure if a members' recommendation is truly made in the best interests of the company.

The result of this study opens new avenue for future research particularly on the extent of application of section 195 of the Companies Act 2016 based on future case laws. Such study will reveal the inclination of the Malaysian court whether it will decide for the company to define what constitutes 'in the best interest of the company' or it will continue to leave the matter in the hands of the directors to determine what is in the best interest of the company in light of section 195. In addition, future research could also draw on cross-countries comparisons by examining availability of members' platform to recommend to the management of the company and such research is to highlight any similarities or differences in their legal operation and to recommend towards enhancement of our section 195 of the Companies Act 2016 itself.

\section{Reference}

Berle, A. A., and Means, G. C., (1932). The Modern Corporation and Private Property. Macmillan: New York

Chan, W.M., (2017). Essential Company Law in Malaysia: Navigating the Companies Act 2016, Sweet \& Maxwell: Kuala Lumpur.

Davies, P.L., (2000). The Board of Directors: Composition, Structure, Duties and Powers, OECD 2001, pp. 1-29

Gillan, S.L., Starks, L.T., (2000). Corporate Governance Proposals and Shareholder Activism: The Role of Institutional Investors. Journal of Financial Economics, 57, pp. 275-305

Khan, H., (2011). A Literature Review of Corporate Governance. IPEDR, 25 pp. 1- 5

Lee, S., (2018). Navigating the Directors' Duty To Act in The Best Interest of The Company: The Petra Perdana Decision and The Companies Act 2016. Retrieved from https://themalaysianlawyer.com/wp-content/uploads/2018/08/Navigating-theDirectors-Duty-Best-Interest-Lee-Shih.pdf

Lee, S., (2017). The Companies Act 2016: Key Changes and Challenges, JMCL, 44(1), pp. 2131

Lopez, D. A., Garcia, L.C., Alvarez, N.G., (2018). Corporate Governance and Innovation: A Theoretical Review. European Journal of Management and Business Economics. Available at https://doi.org/10.1108/EJMBE-05-2018-0056

Mc Convil, J., (2004). Why All Directors Should Be Shareholders in The Company: The Case Against 'Independence', Bond Law Review, 16(2), pp. 40-65.

Mohd Sulaiman, A.N., Bidin, A., Hanrahan, P., Ramsay, I. Stapledon, G., (2008). Commercial Applications of Company Law in Malaysia, 3rd Edition. CCH: Kuala Lumpur.

Mohd Sulaiman, A.N., Othman, E., (2018). Malaysia Company Law: Principles and Practices, 2nd Edition. Wolters Kluwer: Kuala Lumpur.

Ramly, Z., Abdul Rashid, H.M., (2010). Critical Review of Literature on Corporate Governance and the cost of capital: The value creation perspective. African Journal of Business Management, 4(11), pp. 2198-2204

Rampling, P.N., (2012). Shareholder Influence on Board of Directors and CEO Remuneration: A Literature Review. Available at SSRN: https://ssrn.com/abstract=2102136 or http://dx.doi.org/10.2139/ssrn.2102136 
Segrestin, B., Johnston, A., Hatchuel, A. (2018). The Incomplete Separation Of Ownership And Control: Where Are The Managers In Law? Euram European Academy of Management, June 2018, Rekyavik, Iceland. ffhal-01822286f

Zeitlin, M., (1974). Corporate Ownership and Control: The Large Corporation and the Capitalist Class. American Journal of Sociology ,79(5), pp1073-1119.

Cases

Automatic Self-Cleansing Filter Syndicate Co Ltd v Cuninghame [1906] 2 Ch 34

Howard Smith Ltd v Ampol Petroleum Ltd [1974] AC 821

In Re Smith and Fawcett Ltd [1942] Ch 304

Isle of Wight Rly Co v Tahourdin (1884) LR 25 Ch D 320

John Shaw \& Sons (Salford) Ltd v Shaw [1935] 2 KB 113

NRMA Ltd v Parker (1986) 6 NMSWLR 517

Quin \& Axtens v Salmon [1909] AC 442

Tengku Dato' Ibrahim Petra bin Tengku Indra Petra v Petra Perdana Bhd [2018] 2 MLJ 177 